\title{
Danskernes smag for litteratur
}

"Smag og behag er forskellig," lyder et slidt udtryk, men fra litteratur- og kunstsociologien (Bourdieu 1989, Smidt et al. 2013) ved vi, at smagsforskelle langt fra er så tilfældige eller rent subjektive, som udtrykket signalerer. Smagspræferencer og smagsdomme er med til at skabe kulturelle identiteter og hierarkier, ligesom de selv er et produkt af bredere sociale forskelle afspejlet i fx uddannelse og indkomst. Selve udøvelsen og oplevelsen af smag, fx gennem valget eller omtalen af en roman, erfares typisk på et individuelt og subjektivt niveau, men set fra et sociologisk perspektiv må litterær smag tillige belyses på et institutionelt niveau. Smagspræferencer og -hierarkier skabes, reproduceres og udvikles i forskellige institutionelle sammenhænge, herunder uddannelsessystemet, kunstinstitutionen og mediernes populærkultur. I den tidlige litteratursociologi blev sådanne smagshierarkier typisk benævnt henholdsvis "det dannede kredsløb" og "de folkelige kredsløb” (Escarpit 1958, 101 ff.); den første gruppe blev kendetegnet ved en intellektuel og æstetisk dannelse, der satte den i stand til at foretage selvstændige litterære vurderinger, mens de folkelige kredsløb pga. manglende uddannelse blev tilskrevet en "intuitiv litterær smag" (ibid., 102).

Denne typiske modstilling af høj- og lavkultur er siden blevet kritiseret (fx Bürger 1982; Williams 1958), bl.a. fordi dens tydelige normative grundlag a priori gør højkulturen efterstræbelsesværdig, ligesom den kan blokere for en nærmere indsigt i, hvilke motiver og oplevelseskvaliteter der knytter sig til forbruget af den litteratur, som ikke tilskrives høj litterær værdi. Et tredje problem med denne simple skelnen er, at den ikke tager højde for de kulturelle og sociale forandringer, der har gjort sig gældende det sidste halve århundrede. Samfunds- og kulturudviklingen har siden velfærdssamfundets gennembrud i midten af det tyvende århundrede været præget af omfattende forandringer, der også kan tænkes at påvirke befolkningens læsning af bøger og litterære smagspræferencer; det gælder eksempelvis markant forøget uddannelse, voksende urbanisering og større adgang til kultur- og medieprodukter både nationalt og internationalt. Hertel (1999) peger således på en voksende 'me- 
diesymbiose' i efterkrigstidens bogmarked, hvor bl.a. populær- og masselitterære kredsløb interagerer med mediernes kredsløb, og lejlighedsvis sker der også en udveksling mellem speciallitterære kredsløb og den bredere mediekultur.

Kulturpolitikken over for eksempelvis biblioteker har endvidere tilskyndet til en ændret og bredere opfattelse af kvalitet og oplevelser knyttet til læsning af litteratur (Balling 2009). Dertil kommer mere aktuelle forandringer i bogens og litteraturens kredsløb, som kan afsætte spor i danskernes brug af litteratur. Liberaliseringen af bogmarkedet siden 2000 har øget konkurrencen og givet fx supermarkeder adgang til at sælge bøger, og den øgede konkurrence har skabt større fokus på bestsellerlitteratur og populære genrer som kriminallitteratur (Handesten 2014, Phillips 2014). Digitaliseringen af bogen har endvidere givet læserne adgang til at anskaffe og læse bøger online, ligesom nye digitale aktører også med global rækkevidde kan udøve indflydelse på bogens kredsløb i Danmark (Hjarvard og Helles 2015). Der er således brug for en mere opdateret og nuanceret forståelse af litterære smagsforskelles sammenhæng med sociale og kulturelle forhold, herunder en større empirisk fundering af en sådan forståelse.

Eksisterende datakilder til belysning af danskernes læsning af og holdninger til litteratur er noget sporadiske. Kulturministeriets (2012) kulturvaneundersøgelser giver et overblik over nogle få hovedtendenser i befolkningens brug af litteratur i perioden 1964-2012, men er kun blevet gennemført med 6-8 års mellemrum. Dertil kommer en række mere enkeltstående analyser (fx Balling 2009, 2013), der belyser forskellige dimensioner af litteraturlæsningen og dens oplevelseskvaliteter, typisk af mere kvalitativ karakter. Med Bog- og Litteraturpanelets årlige rapport om Bogen og litteraturens vilkår er der siden 2015 skabt et større og mere samlet vidensgrundlag (Kulturstyrelsen 2015, 2016b); denne rapport er dog fortrinsvis baseret på en syntese af eksisterende branchestatistikker ( $\mathrm{fx}$ fra forlag og biblioteker), hvorfor en række mere analytiske spørgsmål om danskernes smagspræferencer kun indirekte belyses. Svagheden beror bl.a. på, at mange datakilder ikke rummer større genreinddelinger og ikke muliggør sammenstilling af forbrugsmønstre og holdninger til litteratur med demografiske baggrundsvariable i større omfang.

I denne artikel belyses danskernes brug af litteratur på baggrund af en spørgeskemaundersøgelse blandt danske læsere. Formålet er at belyse fem forskellige, men sammenhængende forhold: den generelle læseadfærd blandt danskere ( $\mathrm{fx}$ hyppighed), læsernes præferencer for forskellige former for litteratur ( $\mathrm{fx}$ foretrukne genrer), læsernes kilder til at hente inspiration og anskaffe litteratur ( $\mathrm{fx}$ boghandlens betydning), læsernes motiver til at læse bøger (fx ønske om at følge med i aktuel litteratur), samt foretrukne kvalitetskriterier ( $\mathrm{fx}$ at en roman har kunstnerisk værdi). Både fag- og skønlitteratur behandles, men når det gælder smagspræferencer er der fokus på skønlitteraturen. Analysen er overvejende deskriptiv med henblik på at belyse generelle sammenhænge og forskelle i danskernes brug af litteratur, men den er informeret af receptionsteori (Nightingale 2011) samt litteratursociologisk og institutionel teori for derved at skabe en overordnet refleksionsramme til at belyse sammenhænge mellem litteraturlæsning og bredere samfundsmæssige og kulturelle forhold. Et gennemgående analytisk spørgsmål er, i hvilket omfang og på hvilke måder smag for og brug af litteratur er præget af social stratifikation (Harrits 2014). 


\section{Metode}

Analysen bygger på en repræsentativ spørgeskemaundersøgelse foretaget i samarbejde med TNS Gallup. I analysen indgår 1.535 interviews i aldersgruppen 18 år og opefter. Idet formålet med undersøgelsen har været at belyse adfærd og holdninger blandt faktiske læsere af skøn- og/eller faglitteratur, er stikprøven etableret ved en indledende screening af respondenter. Respondenterne er indledningsvist blevet spurgt om frekvensen af deres læsning af bøger, og de respondenter, der har svaret "aldrig" eller "ved ikke", er blevet frasorteret. Ifølge TNS Gallups løbende markedsundersøgelse Index Danmark var der 17,5\% af danskerne, der i 2015 aldrig læste skønlitteratur; for faglitteraturens vedkommende var det 17,4\%. Universet for denne undersøgelse er således alle danskere fra 18 år og opefter, som læser skøn- og/eller faglitteratur med en hyppighed, der går fra "dagligt/næsten dagligt" til "sjældent". Stikprøveusikkerheden vil for den samlede stikprøve $(\mathrm{N}=1535)$ være $\pm 1,1$ for værdier ved 5/95\%, $\pm 2,2$ for værdier ved $25 / 75 \%$ og $\pm 2,4$ for værdier ved 40/60\%. Alle værdier er afrundet til nærmeste hele tal.

Undersøgelsen gjorde brug af TNS Gallups onlinepanel, der også anvendes til en række andre undersøgelser foretaget af TNS Gallup. Undersøgelsen fandt sted i perioden 23. oktober til 12. november 2015. Online-surveyformen giver anledning til en øget usikkerhed for svar vedrørende forholdet mellem læsning af papir- og ebøger. I specielt den helt ældre del af befolkningen er adgang til og brug af internet knap så udbredt, hvorfor en online-survey kan overrepræsentere læsningen af ebøger og anden digital adfærd i denne aldersgruppe, da man i sagens natur kun vil få svar fra personer med adgang til internet. For at give et indtryk af denne usikkerhedsfaktors størrelse i 2015 kan nævnes, at blandt de 16-34 årige var det 97\%, der havde adgang til internettet i hjemmet, mens det i aldersgruppen 65-74 årige var 83\%, og for 75+ årige var det 56\% (Kulturstyrelsen 2016a). For at sikre at også lavfrekvente brugere af internettet (typisk ældre mennesker) blev bedre repræsenteret $\mathrm{i}$ unders $\varnothing$ gelsen, foregik indsamlingen af data over en længere periode (3 uger) end normalt for denne type undersøgelser. Data er desuden blevet vejet i forhold til parametrene $k ø n$, alder, uddannelse, antal personer i husstanden, landsdel og livsstilssegmenteringen Gallup Kompas for at sikre, at resultaterne er repræsentative. I artiklen trækkes der tillige på andre undersøgelser og datakilder.

\section{Bogen mellem skole, kunst og medier}

Bøger indgår i både materielle og symbolske kredsløb: de udgør fysiske artefakter og varer med økonomisk værdi og rummer tillige symbolsk indhold, der både refererer til og medskaber den sociale og kulturelle verden, læseren indgår i. Bøger skabes og læses i mange forskellige sammenhænge, men fra et sociologisk og overordnet perspektiv kan man sige, at bogens kredsløb fortrinsvis er reguleret af tre institutionelle sammenhænge: den litterære institution, skolen som institution og populærkulturen som institution (figur 1). Disse tre institutionelle domæner påvirker på forskellig måde produktionen, distributionen og forbruget af bøger. Institutioner skal ikke forveksles med konkrete organisationer som Politikens Forlag eller Dansk Forfatterforening. Ved en institution skal vi forstå et bestemt om- 
råde af kultur og samfund, som har en vis autonomi, og hvor mennesker varetager bestemte opgaver. Typiske institutioner er fx familien, skolen, staten og markedet. Institutioner er på én og samme tid materielle og symbolske, og deres virke er reguleret og afhængig af regler og ressourcer. Ser vi på den litterære institution er den styret af formelle regler (fx kontrakter mellem forlag og forfatter), uformelle regler ( $\mathrm{fx}$ normer for litteraturkritik), materielle ressourcer ( $\mathrm{fx}$ forfatterhonorarer) og symbolske ressourcer ( $\mathrm{fx}$ litterære priser). For en uddybning af institutionsbegrebet se fx Thornton et al. (2012) og Hjarvard (2016).

Hver af disse tre institutioner er præget af bestemte opfattelser af bogens rolle, herunder normative idealer for, hvilke formål bogen skal tjene. I skolen er bogen et privilegeret medium for oplysning og læring og i bredere forstand dannelse. Dette er ikke mindst faglitteraturens og lærebogens domæne, og her spiller videnskabelig og faglig ekspertise en stor rolle for reguleringen af bøgers udgivelse og brug. I den litterære institution opfattes bogen først og fremmest som et medium for kunst og kultur. Her styres vurderingen af bøgers værdi af litterært-æstetiske normer; dette er skønlitteraturens, herunder poesiens privilegerede domæne, hvor fx litteraturpriser og anmeldere spiller en vigtig rolle for afsigelsen af smagsmæssige domme. Endelig er der populærkulturen, hvor bogen er et medie på lige fod med andre medier som film, tv og computerspil, og hvor underholdningsværdi spiller en fremtrædende rolle for en bogs succes. Her spiller også bogens økonomiske værdi som vare en vigtig rolle for, hvad der opnår udgivelse og eksponering.

De tre institutionelle kontekster udøver forskelligartet indflydelse på bøger og litteratur, men det er vigtigt at understrege, at der trods den idealtypiske bestemmelse af tre forskellige institutioner ofte er et samspil mellem dem. Den litterære institutions værdier er i høj grad blevet indoptaget i skolesystemet, hvor ikke mindst danskfaget, men også andre sprogfag, giver arbejdet med litterære værker en høj prioritet. Tilsvarende har udøvere af litterær kritik i dagbladene ofte en længerevarende uddannelse, ligesom flere af dem er ansat som forskere og undervisere ved universiteterne. Samtidig er skønlitteraturen og den almene faglitteratur en del af det almindelige bogmarked, hvor de konkurrerer om opmærksomhed med populærlitteratur og andre medie- og underholdningstilbud. En klassisk skelnen i bogbranchen går mellem 'børs og katedral', hvorved forstås en grundlæggende konflikt mellem hensynet til økonomisk indtjening og ideale fordringer om æstetisk kvalitet og læringsmæssig værdi (Schiffrin 2010, Thompson 2010). Den øverste halvdel af trekanten i figur 1 er således 'katedralens' domæne, idet hensynet til kunst og viden her er fremherskende. Den nederste halvdel af trekanten hører til 'børsens' domæne, da hensynet til underholdning og indtjening dominerer her. Det er dog ikke fundamentalt adskilte hensyn, men typisk nogle som konkrete aktører må balancere i forhold til hinanden, hvor fx forlag bruger bestsellerlitteratur til at finansiere smallere, kunstneriske udgivelser.

Forholdet mellem de tre institutioner er ikke statisk, og deres indflydelse på forskellige sider af bogens kredsløb kan variere. Inden for forlagsbranchen har man i de sidste årtier kunnet iagttage en øget påvirkning fra et populærkulturelt 


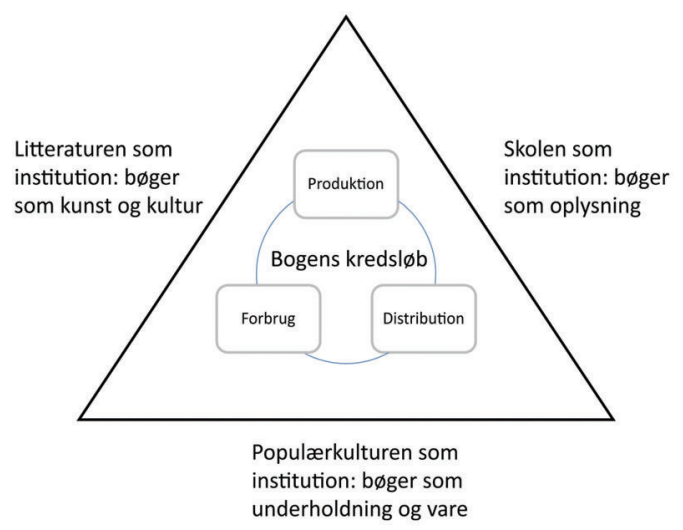

Figur 1. Bogens kredsløb under indflydelse af tre institutionelle domæner: Den litterære institution, skolen som institution og populærkulturen som institution.

mediemarked, hvor underholdning og markedsindtjening i højere grad fungerer som styringsparametre (Schiffrin 2010, Thompson 2010). Forlagsdirektør Stig Andersen fra Gyldendal peger eksempelvis selv på, hvordan denne udvikling har udfordret de sædvanlige kvalitetskriterier i den redaktionelle proces, fx i udgivelsen af Fifty Shades of Grey på dansk: "Gyldendal står for kvalitet og mangfoldighed. Derfor var vi også i tvivl, om vi skulle lave Fifty Shades of Grey. Men det er vi jo altså glade for, for den har indtjent os en masse penge" (Interview 13.4.14, Hjarvard og Helles 2015). Forandringen i bogens kredsløb kan også beskrives som led i en medialiseringsproces (Hjarvard 2016), hvor bogen i voksende omfang bliver en del af en bredere mediekultur og dermed i højere grad underlagt de generelle dynamikker, som præger mediekulturen. Selvom medialiseringen således har været katalysator for en kommercialisering, er der også eksempler på andre udviklingstendenser. Eksempelvis har udbredelsen af e-bogen givet nyt liv til udgivelse af lyrik, der ellers har svært ved at klare sig $\varnothing$ konomisk i den trykte form (Kulturstyrelsen 2016b), ligesom internettet generelt har gjort det muligt for læsere at udgive, diskutere og evaluere litteratur og dermed skabt konkurrence til både kommercielle forlag og etablerede kritikere (Kristensen og From 2015).

De tre institutionelle kontekster præger også læsningen af bøger, herunder de smagskriterier, som læserne tager i anvendelse, og de typer af oplevelser og erfaringer, som læseren efterspørger i sin læsning af litteratur. I denne analyse skal den institutionelle ramme dels skabe en generel begrebsmæssig kontekst for at belyse bogens kredsløb og dels mere specifikt bruges til at undersøge, i hvilket omfang forskellige typer af læsning er orienteret mod eller frakoblet de tre forskellige institutioner. Det er således hypotesen, at læsernes egne erfaringer med uddannelsesinstitutionen (fx målt gennem læserens uddannelsesbaggrund) og den litterære institution (fx målt gennem hyppighed af læsning af anmeldelser) hænger sammen med de anvendte smagskriterier. 


\section{Læsere og ikke-læsere}

Ser vi indledningsvist på, hvor hyppigt danskerne læser bøger, kan vi af figur 2 og 3 se, at der har været en betydelig stabilitet i læsefrekvensen i perioden 2010-15. Gennem denne periode læste 16-17\% af danskerne skønlitteratur dagligt eller næsten dagligt, mens knap 40\% læste mindst én gang om ugen. I 2015 havde 38\% læst skønlitteratur mindst én gang om ugen (= summen af '1-2 dage om ugen', '3-4 dage om ugen' og 'dagligt/næsten dagligt').

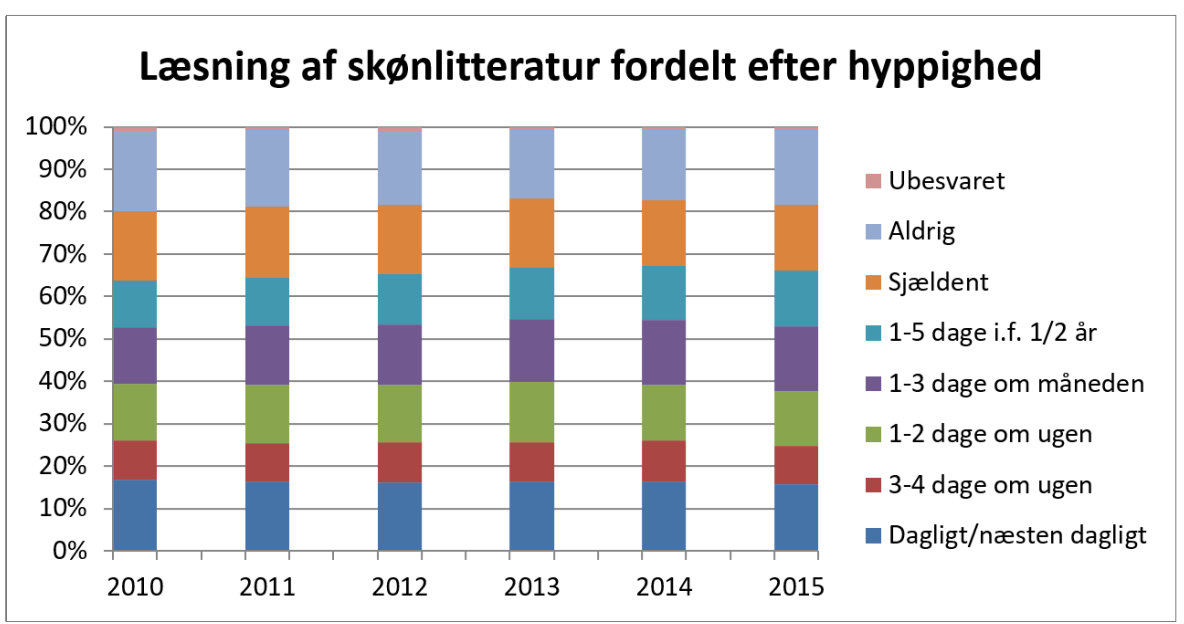

Figur 2. Procentuel fordeling af læsefrekvens i den danske befolkning fra 15 år og opefter. Kilde: TNS Gallup: Index Danmark og Kulturstyrelsen (2016b).

Når det gælder faglitteratur, ser vi en tilsvarende stabilitet over tid, og her angiver omkring 9-13\% af befolkningen, at de læser faglitteratur dagligt eller næsten dagligt. Omkring 33-35\% læser faglitteratur ugentligt. I 2015 var det 35\%, der læste faglitteratur mindst én gang om ugen.

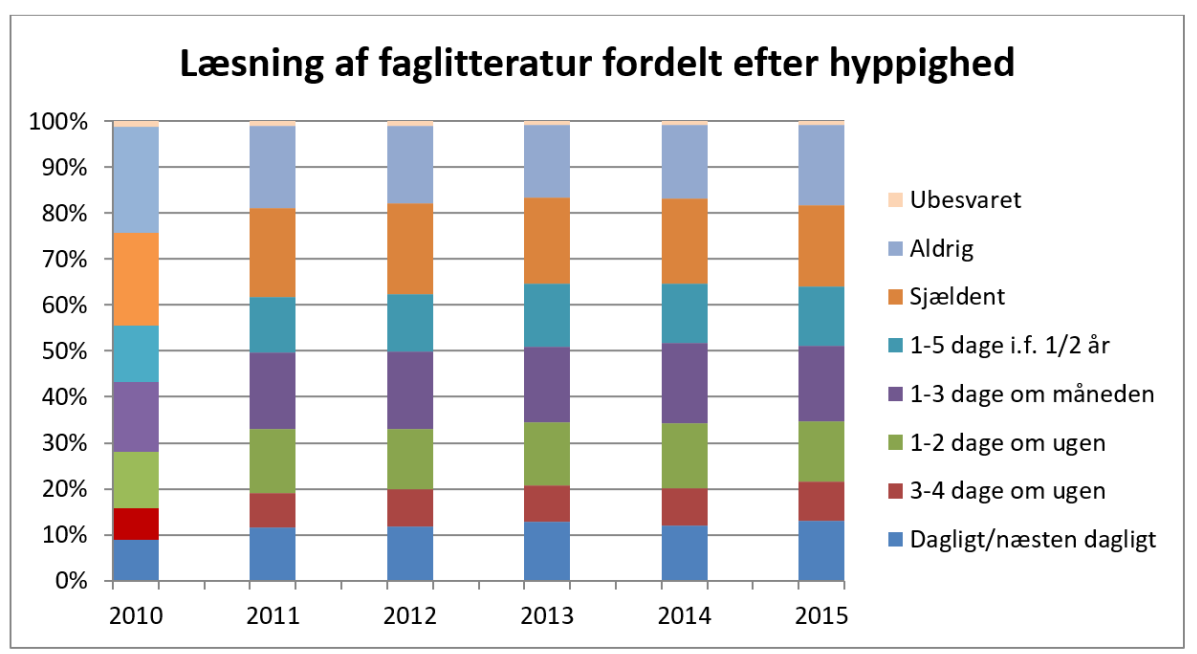

Figur 3. Procentuel fordeling af læsefrekvens i den danske befolkning fra 15 år og opefter. Kilde: TNS Gallup: Index Danmark og Kulturstyrelsen (2016b). 
Bag de generelle læsertal for alle danskere gemmer der sig en række markante forskelle. Kvinder læser langt hyppigere skønlitteratur end mænd; 47\% af kvinderne angiver i 2015, at de læser skønlitteratur ugentligt eller hyppigere, mens det kun er 29\% af mændene, der læser så hyppigt. Når det gælder faglitteratur, er mændene de flittigste læsere, idet 38\% læser faglitteratur mindst en gang om ugen, hvor 32\% af kvinderne læser med denne hyppighed (Kulturstyrelsen 2016b). Hvis vi vender os fra de flittigste læsere til de danskere, der aldrig læser skøn- og faglitteratur, henholdsvis $18 \%$ og 17\% i 2015, kan vi se, at økonomi og uddannelse spiller et rolle for dette. Ser vi på danskere med en husstandsindkomst op til 200.000 kr., angiver 31\% at de aldrig læser faglitteratur, og 22,2\% læser aldrig skønlitteratur. I den anden ende af det $\varnothing$ konomiske spektrum, hos personer med en husstandsindkomst på 1 million kr. eller derover, angiver kun 5\%, at de aldrig læser faglitteratur, mens 8\% aldrig læser skønlitteratur. Sagt på en anden måde er det blandt de rigeste danskere kun hver tyvende, der aldrig læser faglitteratur, hvorimod det næsten er hver tredje blandt de fattigste danskere. Når det gælder uddannelse, finder vi i gruppen af danskere med den laveste uddannelsesbaggrund (folkeskole 7-10 år) 26\%, der aldrig læser skønlitteratur. Blandt de højest uddannede med en lang eller mellemlang videregående uddannelse, finder vi kun 5-6\%, der aldrig læser skønlitteratur (Kulturstyrelsen, 2016b). Det interessante er videre, at hvis vi i stedet fokuserer på de personer, der hyppigt læser bøger, finder vi ikke helt samme entydige sammenhænge mellem læsning og økonomi. Med andre ord: hvis først folk læser bøger med en vis hyppighed, er sammenhængene mellem læsemønstre og demografiske faktorer mere sammensatte.

\section{Litterære genrers demografi}

Til at belyse læsernes smagspræferencer inden for skønlitteraturen vil jeg tage afsæt i en distinktion mellem udbredte genrer, idet genrer også fungerer som et klassifikationssystem for læseren i forhold til forventede oplevelser (Palmer 1990). En genrekategorisering stiller problemet, hvordan man håndterer den litteratur, der vanskeligt lader sig kategorisere i forhold til bestemte genrer eller ikke kan forstås som 'genrelitteratur'. Smalle eller komplekse genrer er vanskelige at anvende i en surveyanalyse; her stilles der krav om almen genkendelse af kategorier og en vis udbredelse for at sikre en målelig svarprocent. Løsningen har været at bruge kategorien "skønlitteratur uden bestemt genre"; denne kategori sikrer, at valgmuligheden kan opnå tilstrækkeligt mange svar, ligesom det bliver muligt at se, i hvilket omfang læserne har præference for litteratur, der ikke forlods er genrebestemt. For at skabe et mere nuanceret billede af smagspræferencerne har respondenterne haft mulighed for at afkrydse to svarmuligheder, når de er blevet spurgt om, "hvilke typer af romaner holder du mest af at læse"; hvis der kun var givet én svarmulighed, kunne det muligvis fortegne præferencen for meget populære genrer, fx kriminallitteratur.

Som det fremgår af figur 4, er kriminalromaner klart den mest foretrukne genre; næsten halvdelen af læserne angiver denne genre som sit foretrukne valg. Dernæst følger skønlitteratur uden bestemt genre og historiske romaner som de mest foretrukne genrer. Fantasy og science fiction, thrillere og gysere, kærlighed og erotik 
samt humor og satire er genrer med appel til en mindre del af læserskaren sammenlignet med de tre førstnævnte genrer. Det er værd at understrege, at læserne også kan læse anden litteratur end deres foretrukne genrer; figur 4 viser alene, hvilke genrer de selv angiver at have en forkærlighed for. Når det gælder kriminalromaner, angiver 48\% af læserne, at de læser mindst én kriminalroman hvert halve år, mens kun $22 \%$ angiver, at de aldrig læser kriminalromaner. Som helhed kan man sige, at læsernes præferencer afspejler en udvikling, hvor kriminallitteratur er blevet ikke bare mainstream, men den helt dominerende genre. Dette er også synligt i boghandlernes bestsellerlister og forlagenes markedsføring, og genrens vækst er desuden sket på tværs af flere medier, ikke mindst bøger og tv (Agger 2010, Povlsen 2016).

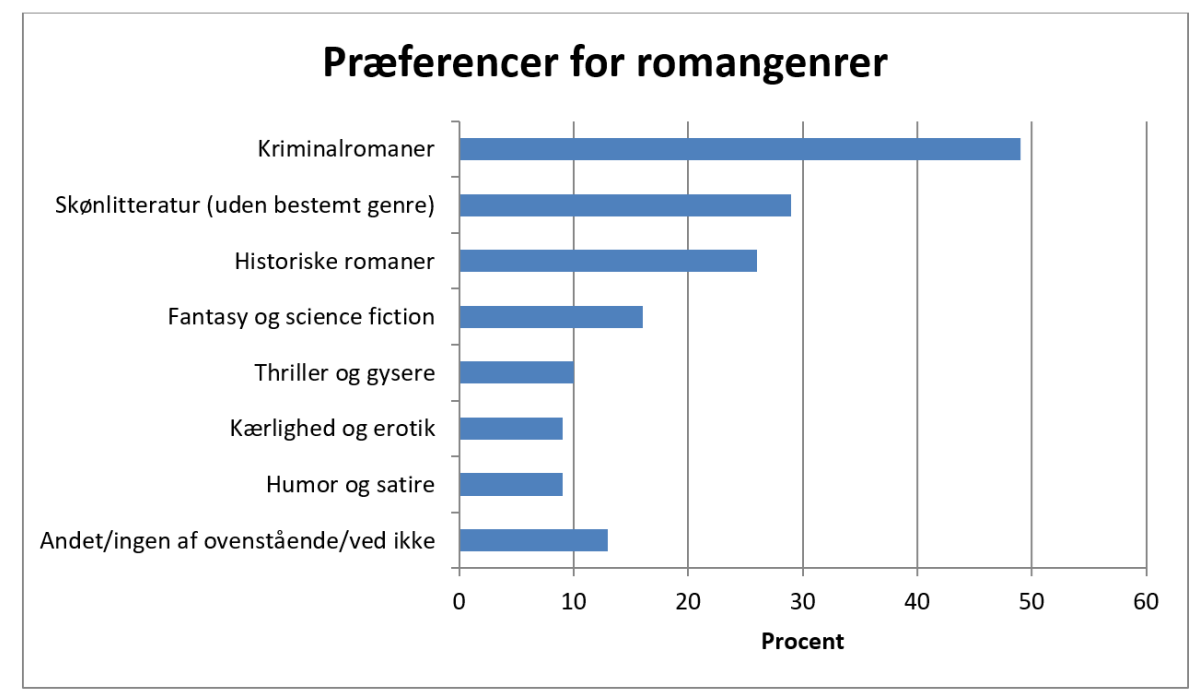

Figur 4. Spørgsmål: "Hvilke typer af romaner holder du mest af at læse?" (højst 2 svar). Egen undersøgelse i samarbejde med TNS Gallup. N=1535. Univers er alle danskere i aldersgruppen fra 18 år og opefter, der læser bøger.

Ser vi nærmere på, hvad der kendetegner læserne med præference for de forskellige genrer, viser figur 5 , at køn spiller en rolle i flere tilfælde. Kvinder foretrækker kærlighed og erotik i højere grad end mænd, og det gælder også skønlitteratur uden genre. Mænd har i højere grad end kvinder præference for fantasy og science fiction, thrillere og gysere samt humor og satire. Kriminalromaner er i lidt højere grad foretrukket af kvinder end mænd, men der er ikke tale om den store forskel. Det er i øvrigt værd at medtænke det tidligere nævnte forhold, at kvinder generelt læser skønlitteratur langt hyppigere end mænd. Hvad vi ser afspejlet i figur 5, er således alene kønsmæssige forskelle i selvangivne præferencer; det kan ikke direkte oversættes til forskelle i omfang eller hyppighed af læsning mellem de to køn. 


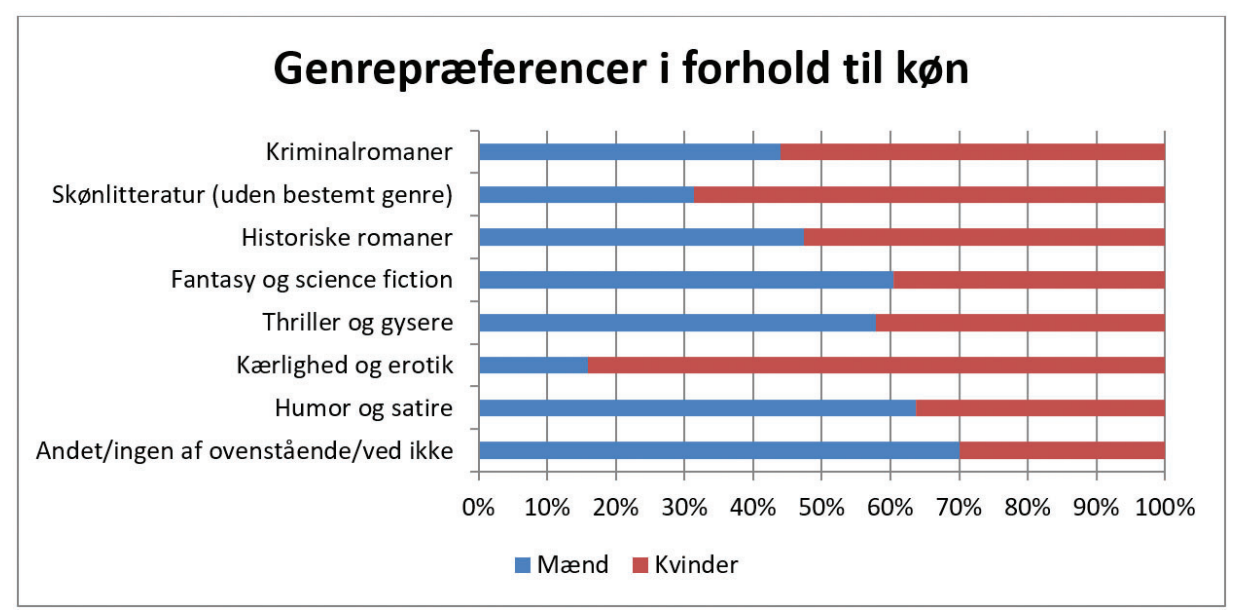

Figur 5. Genrepræferencer i forhold til køn. Spørgsmål: "Hvilke typer af romaner holder du mest af at læse?" (højst 2 svar). Egen undersøgelse i samarbejde med TNS Gallup. N=1535. Univers er alle danskere i aldersgruppen fra 18 år og opefter, der læser bøger.

Der gør sig også en række alders- og uddannelsesmæssige forskelle gældende. Figur 6 viser, at især fantasy og science fiction er foretrukken blandt yngre læsere, mens historiske romaner, skønlitteratur uden bestemt genre og kriminalromaner er foretrukne blandt ældre læsere. Læsere med forkærlighed for kærlighed og erotik samt thrillere og gysere har en bredere aldersmæssig sammensætning. Ser vi på uddannelsesmæssige forskelle i figur 7, udmærker skønlitteratur uden genre sig ved at være den foretrukne form for litteratur blandt læsere med den længste uddannelse; mere end halvdelen har her en videregående uddannelse af kortere eller længere varighed. Videregående uddannelse præger også læsere med forkærlighed for historiske romaner, mens thrillere og gysere befinder sig i den anden ende af det uddannelsesmæssige spektrum. Læsere med præference for kriminalromaner ligger uddannelsesmæssigt tæt på den samlede population af læsere.

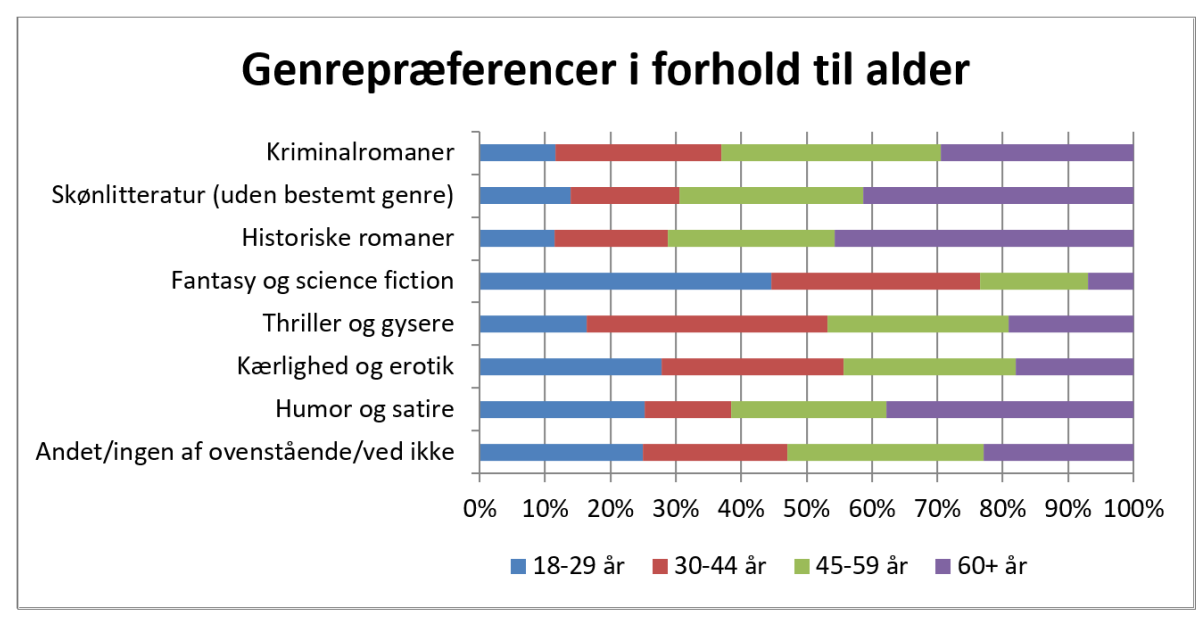

Figur 6. Genrepræferencer i forhold til alder. Spørgsmål: "Hvilke typer af romaner holder du mest af at læse?" (højst 2 svar). Egen undersøgelse i samarbejde med TNS Gallup. N=1535. Univers er alle danskere $\mathrm{i}$ aldersgruppen fra 18 år og opefter, der læser bøger. 


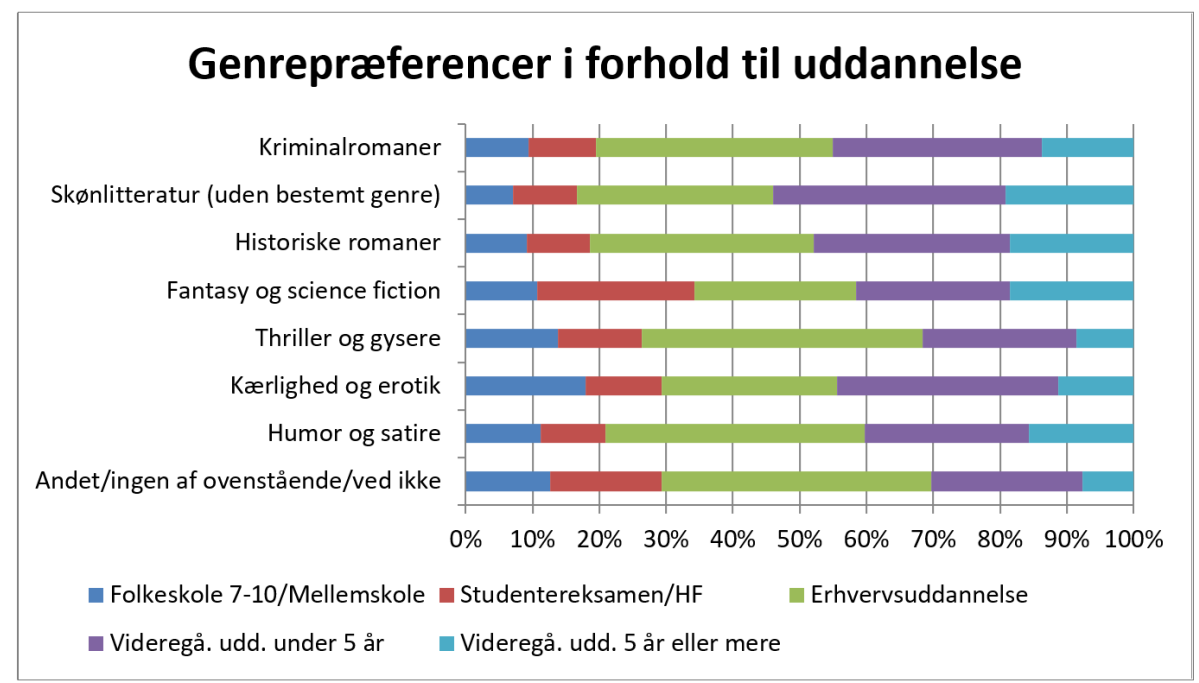

Figur 7. Genrepræferencer i forhold til uddannelse. Spørgsmål: "Hvilke typer af romaner holder du mest af at læse?" (højst 2 svar). Egen undersøgelse i samarbejde med TNS Gallup. N=1535. Univers er alle danskere i aldersgruppen fra 18 år og opefter, der læser bøger.

\section{Bøger på skærm og papir: læsning på tværs}

Læsning af e-bøger er siden 2013 gradvist begyndt at blive et mere udbredt fænomen, hvor det tidligere var en mere marginal foreteelse (Hjarvard og Helles 2013). Ser vi på universet af danske boglæsere, angiver 3\%, at de læser e-bøger dagligt, mens $8 \%$ læser e-bøger ugentligt. I alt siger 24\% af boglæserne, at de læser e-bøger mindst en gang om året, mens $76 \%$ sjældnere eller aldrig læser e-bøger (figur 8). Det er imidlertid værd at understrege, at hverken denne eller andre analyser peger på, at læsning af e-bøger i større omfang erstatter læsning af papirbøger. Ser vi på den gruppe af boglæsere, der læser e-bøger mindst én gang om måneden, læser 76\% også papirbøger mindst en gang om måneden. Ser vi på de boglæsere, der sjældnere eller aldrig læser e-bøger, er det kun 64\%, der læser papirbøger mindst en gang om måneden. De nuværende e-bogslæsere er med andre ord hyppige læsere, både på papir og digitalt, og brugen af skærm til boglæsning kan for nogle ses som

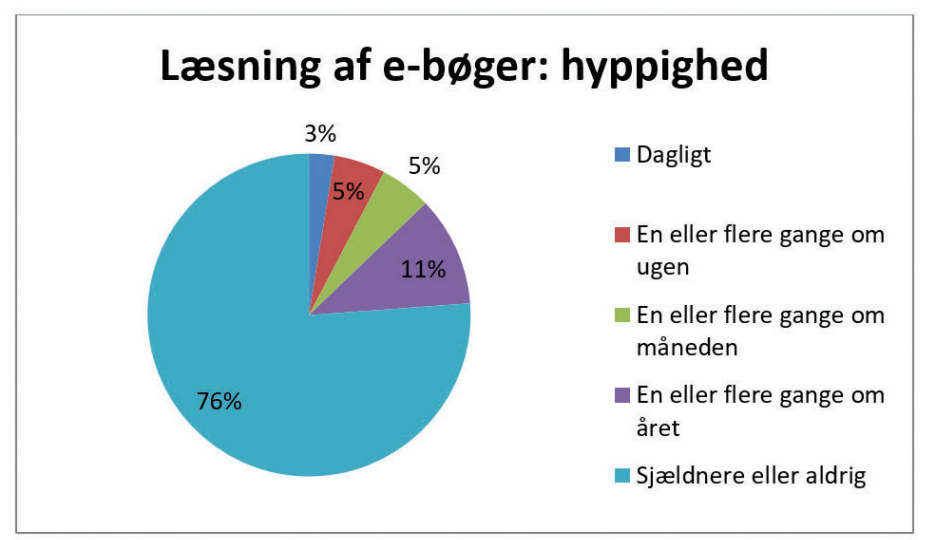

Figur 8. Læsning af e-bøger i Danmark i 2015 og opefter. Egen undersøgelse i samarbejde med TNS Gallup. $N=1535$. Univers er alle danskere i aldersgruppen fra 18 år og opefter, der læser bøger. 
en måde at skabe flere og mere fleksible muligheder for at læse bøger. Dette forhold kan naturligvis ændre sig, i takt med at e-bogslæsning bliver udbredt til større dele af befolkningen.

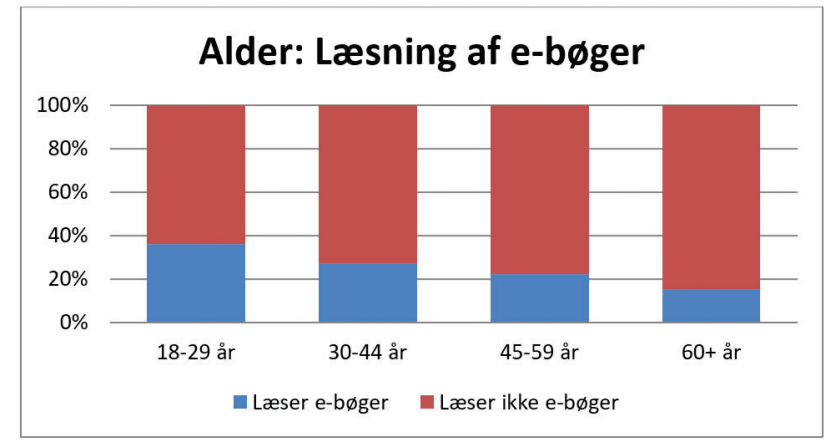

Figur 9. Aldersfordeling af e-bogslæsere og ikke-e-bogslæsere. Ved en e-bogslæser forstås her en læser, der læser e-bøger mindst en gang om året. Egen undersøgelse i samarbejde med TNS Gallup. $\mathrm{N}=1535$. Univers er alle danskere i aldersgruppen fra 18 år og opefter, der læser bøger.

Vi finder ikke overraskende flere yngre læsere af e-bøger (figur 9), hvilket afspejler det generelle forhold, at digital og mobil teknologi hyppigere bruges i den yngre del af befolkningen. Det er mere interessant at konstatere, at også den midaldrende og ældre del af befolkningen bruger e-bøger. For $60+$ alderssegmentet skal der som nævnt i metodeafsnittet dog tages et vist forbehold; her kan være en relativ overvurdering af hyppigheden af e-bogslæsning. Ser vi på, hvilke skærme eller teknologier der anvendes til e-bogslæsning, er det ganske tydeligt, at især tablet-computere, men også mobiltelefoner anvendes til at læse bøger (figur 10). Dedikerede e-bogslæsere af typen Amazon Kindle eller Sony Reader spiller en ganske beskeden rolle. Måske overraskende spiller også en pc/mac computer en vigtig rolle for de 18-29 åriges boglæsning, men dette afspejler givetvis, at de i studiesammenhæng anvender en sådan.

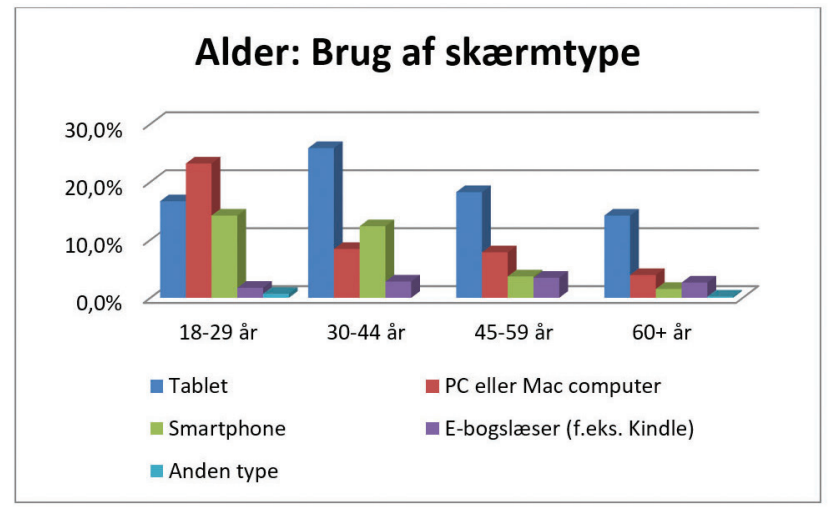

Figur 10. Brug af skærmtype til e-bogslæsning i 2015; flere svar er mulige. Egen unders $\varnothing$ gelse i samarbejde med TNS Gallup. $N=1535$. Univers er alle danskere i aldersgruppen fra 18 år og opefter, der læser bøger. 
Ser vi på, hvor danskerne henter e-bøger på internettet (figur 11), er det tydeligt, at danske biblioteker spiller en vigtig rolle; $32 \%$ af e-bogsbrugere har brugt danske bibliotekers e-bogsudlån. Andre vigtige kilder er gratis samlinger på internettet (25\%), Saxo.com (22\%), Mofibo (14\%), Apple (13\%), Amazon (11\%), og Google (9\%). Det er værd at bemærke, at også DR (9\%) og Riidr (7\%) leverer stof til danskernes e-bogslæsning, mens danske forlags hjemmesider (5\%) og udenlandske biblioteker (3\%) spiller en mere marginal rolle.

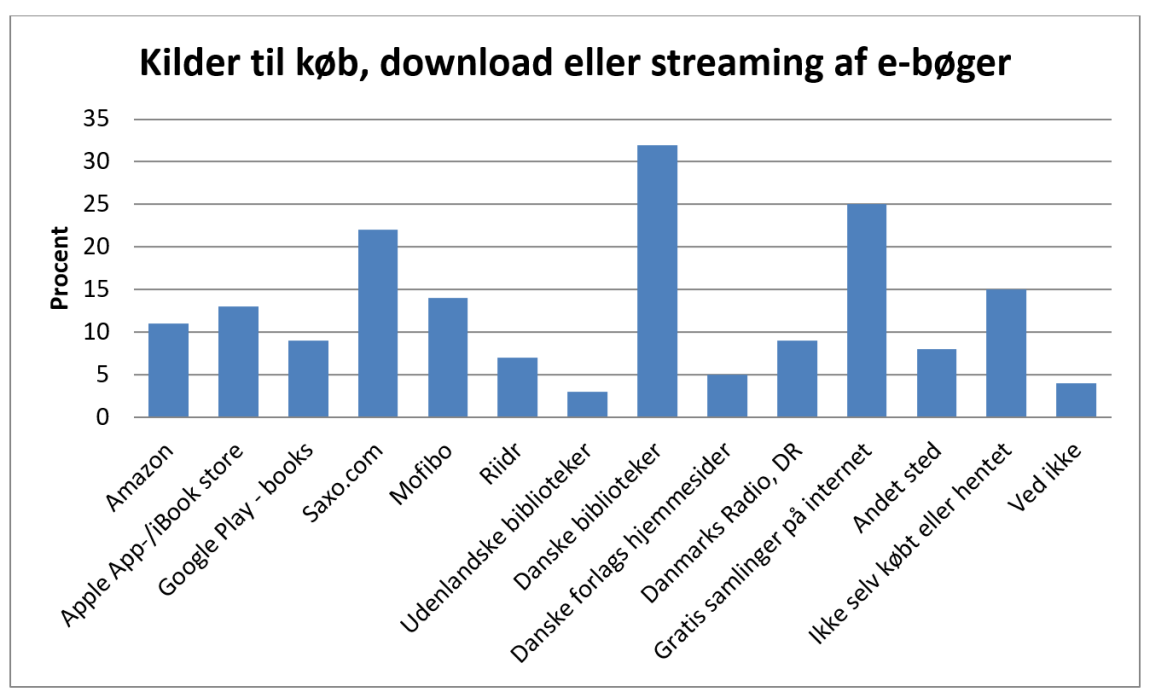

Figur 11. Spørgsmål:"Hvor har du nogensinde købt eller hentet e-bøger?”. Flere svar er mulige. Egen undersøgelse i samarbejde med TNS Gallup. N=444. Univers er e-bogslæsere.

\section{Motiver til læsning og kilder til inspiration}

Læsningen af skønlitteratur tjener først og fremmest et individuelt og rekreativt formål. Spørger man læseren om, hvad der primært driver læsningen af skønlitteratur, er de to altdominerende svar, at "jeg vil slappe af og have tid for mig selv" (61\%), og at "jeg vil have spænding og underholdning" (40\%). En bredere samfundsmæssig, kulturel eller æstetisk interesse er knap så fremherskende. $25 \%$ nævner, at "jeg vil blive klogere på mennesker, kultur og samfund", og kun 5\% nævner, at "jeg vil følge med i aktuel litteratur". Måske overraskende svarer kun beskedne $4 \%$, at de vil have stof til at tale med andre (figur 12). Der er ikke nævneværdige forskelle mellem papirbogs- og e-bogslæsere; e-bogslæsere angiver dog i lidt højere grad, at de vil slappe af og have tid for dem selv. Analysen peger videre på, at det er vigtigt at skelne mellem, hvad der er primære motiver til læsning, og hvilke sociale funktioner bøger også indgår i. Selvom selve læsningen ikke er socialt motiveret, men tværtimod understøtter en tilbagetrækning fra sociale sammenhænge (både individuelt og samfundsmæssigt), indgår bøger og læsning som en aktiv del af sociale kredsløb. Som det fremgår af figur 13 , taler $2 /{ }_{3}$ af læserne ofte eller en gang imellem med andre om bøger, de læser. Bogen er også et hyppigt anvendt gaveobjekt, idet ${ }^{2} / 3$ af læserne enten ofte eller en gang i mellem giver bøger i gave til familie eller venner $\mathrm{fx}$ til fødselsdag eller jul (figur 14). Læsere af e-bøger skiller sig en smule ud, idet de i endnu højere 
grad end papirbogslæsere taler med andre om bøger og giver bøger i gave. Det peger på den tidligere nævnte pointe, at e-bogslæsere generelt er mere flittige læsere og dermed også er interesserede i at tale om og give bøger.

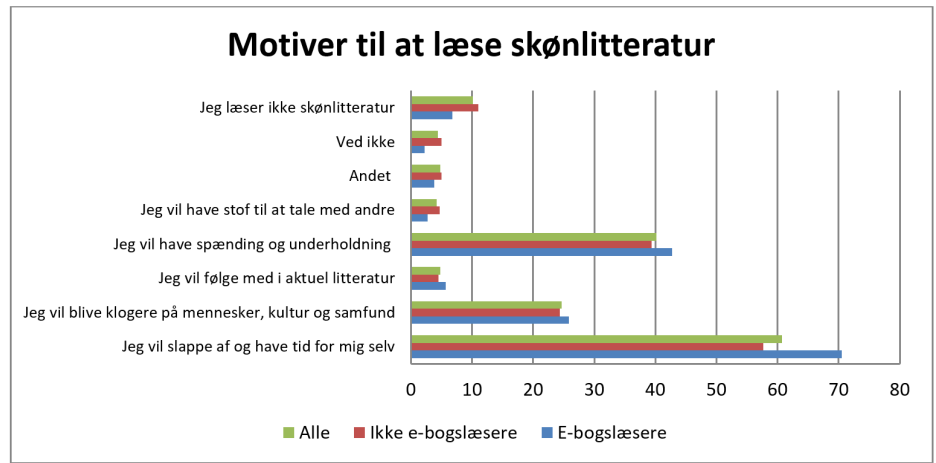

Figur 12. Svar i procent på spørgsmålet "Hvad får dig primært til at læse skønlitteratur?", højst 2 svar. Egen undersøgelse i samarbejde med TNS Gallup. $N=1535$. Univers er alle, der læser bøger, i aldersgruppen fra 18 år og opefter.

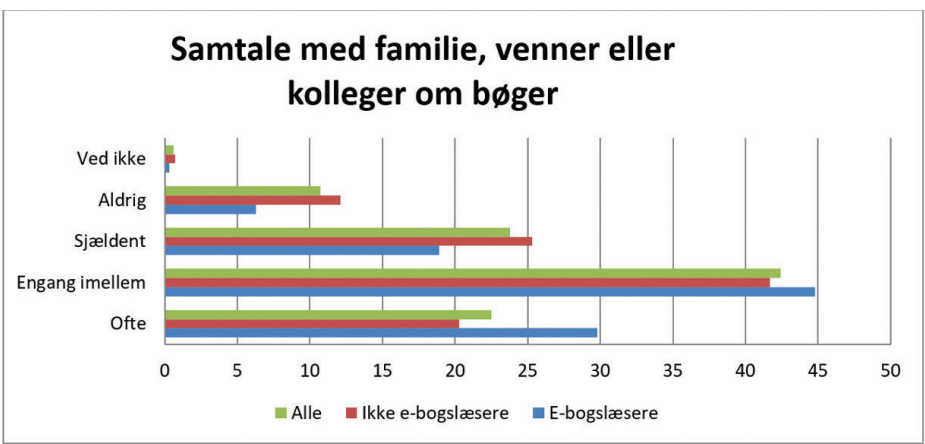

Figur 13. Svar i procent på spørgsmålet: "Hvor ofte taler du med f.eks. familie, venner eller kolleger om bøger, du læser?” Egen undersøgelse i samarbejde med TNS Gallup. N = 1535. Univers er alle, der læser bøger, i aldersgruppen fra 18 år og opefter.

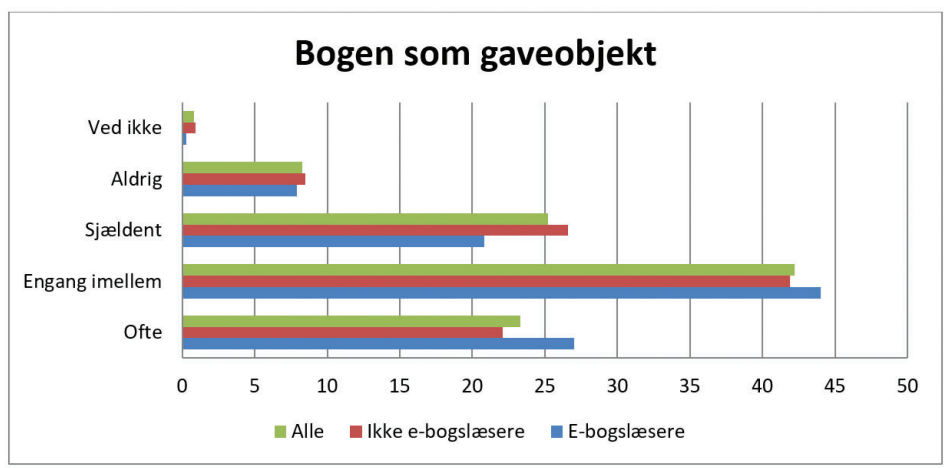

Figur 14. Svar i procent på spørgsmålet: "Hvor ofte forærer du en bog til familie og venner fx til fødselsdag eller jul?" Egen undersøgelse i samarbejde med TNS Gallup. N = 1535. Univers er alle, der læser bøger, i aldersgruppen fra 18 år og opefter. 
Den sociale dimension ved litteraturen afspejler sig også i de kilder, som læserne anvender til at finde inspiration til, hvad de næste gang skal læse (figur 15). Det viser sig, at samtaler med venner og bekendte er den mest udbredte kilde til inspiration; 49\% af læserne nævner dette. Dernæst er de tre vigtigste kilder til inspiration biblioteker (31\%), anmeldelser i dagblade (30\%) og boghandlere (29\%). En række medier spiller også en vis rolle, men ikke i samme omfang som de førnævnte kilder. Supermarkederne nævnes som inspirationskilde i samme omfang som litteratursider på internettet.

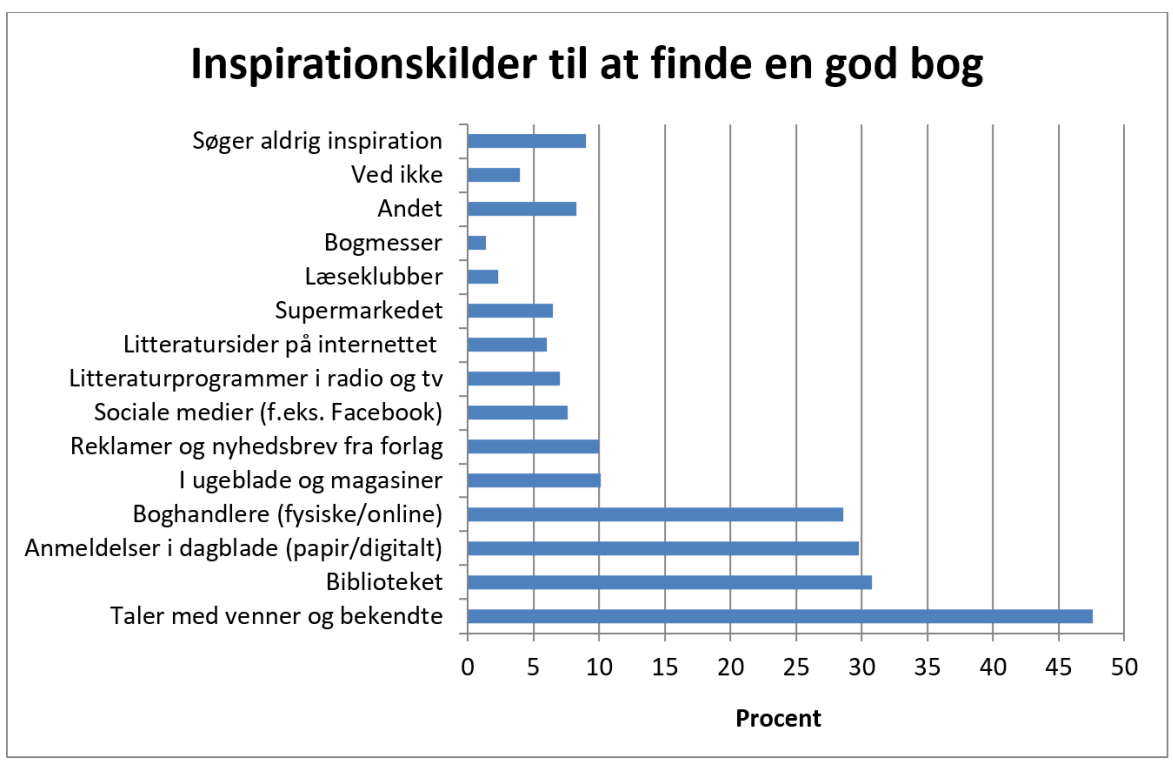

Figur 15. Svar i procent på spørgsmålet: "Hvis du søger inspiration til at læse en god bog, hvor søger du så inspiration henne?", højst 3 svar. Egen undersøgelse i samarbejde med TNS Gallup. N = 1535. Univers er alle, der læser bøger, i aldersgruppen fra 18 år og opefter.

\section{Kvalitetsparametre og typer af læsning}

Som afsæt for en nærmere belysning af, hvilke smagsforskelle der kendetegner danskernes læsning af skønlitteratur, er respondenterne blevet præsenteret for en række valgmuligheder i forhold til spørgsmålet om, hvad de synes bedst kendetegner en god roman. Svarmulighederne er konstrueret på baggrund af dominerende kvalitetskriterier inden for hver af de tre førnævnte institutioner (figur 1), og med inspiration fra Mukařovskýs (1977) diskussion af læserens perception er disse kriterier videre grupperet i henholdsvis vurderende og oplevelsesorienterede kriterier. Mukařovský skelner mellem en læsning, der har en umiddelbart oplevende holdning til litteraturen, og en læsning, der er mere distanceret og æstetisk vurderende (Mukařovský 1977, Smidt 2011). I den første type af læsning tilegner læseren sig det fiktive univers på en indlevende måde, hvor læseren opsluges af det fiktive univers og ikke ser det som et intenderet kunstnerisk værk. I den distancerede læsning er der en mere vurderende relation til forfatterens intenderede fremstilling af historien. De to læsemåder er ikke gensidigt udelukkende, og i forlængelse af Mukařovskýs opfattelse af 
mennesket som grundlæggende poly- eller multifunktionelt i sin omgang med omverdenen kan den konkrete læser bruge den skønlitterære læsning til flere formål, fx at få æstetiske oplevelser, opsøge konkret information eller opnå social prestige (Balling 2009).

Mens den overordnede distinktion mellem den oplevende og den vurderende læsning er inspireret af Mukařovský, er den nærmere bestemmelse og gruppering af smagspræferencer og kvalitetskriterier som nævnt informeret af min institutionelle forståelsesramme for bogens cirkulation. Da analysen af læsernes smags- og kvalitetsopfattelser er fokuseret på skønlitteratur, vil jeg ikke inddrage kriterier, der fortrinsvis knytter sig til faglitteratur eller læsning, der tjener instrumentelle, herunder informationssøgende formål. Set i forhold til det klassiske skel mellem 'nytte-læsning' og 'fornøjelseslæsning' (Berntsen og Larsen 1993) forholder vi os i denne sammenhæng primært til smagspræferencer inden for den sidstnævnte, selvom der naturligvis også kan være informative eller nyttemæssige aspekter knyttet til læsningen af skønlitteratur.

De vurderende kriterier er opdelt i forhold til tre forskellige egenskaber, der typisk indgår i en vurdering af litterær kvalitet, henholdsvis dens kunstneriske kvalitet, sproglige kvalitet og emnemæssige relevans, hvor det sidste skal forstås som en vurdering af, om en roman sætter vigtige emner til debat. De vurderende kriterier kan siges at pege udad i kultur og samfund i den forstand, at læseren med sin vurdering sætter en romans kvaliteter i relation til kollektive normer for kunst, sprog og samfundsmæssig relevans. De vurderende kriterier dominerer typisk i to institutionelle kontekster, den litterære institution og skolen som institution. De oplevelsesorienterede kriterier peger i højere grad indad mod den subjektive erfaring og tilfredsstillelse, herunder den underholdende funktion ved læsningen. Disse kvalitetskriterier udgår i højere grad fra populærkulturens domæne, men de finder i varierende grad også anvendelse inden for de to øvrige institutioner. Her skelnes der også mellem tre svarmuligheder: om romanen rummer en god historie, hvor appellen ved det narrative univers og dets udvikling er i centrum; om hovedpersonerne er lette at identificere sig med, hvilket sætter fokus på den psykologiske indlevelse i fiktive personer, og for det tredje om fortællingen er spændende, hvor det er underholdningsfunktionens kvalitet, der er i centrum. Af metodiske årsager er svarmuligheden "fortællingen er underholdende" ikke valgt, da 'underholdning' både kan opfattes meget bredt og forstås som en afgrænset genre, ligesom 'underholdning' kan have normative medbetydninger, som det ikke er ønskeligt at aktualisere i et spørgeskema. Det er værd at understrege, at de i alt seks forskellige svarmuligheder ikke er gensidigt udelukkende; en konkret læser kan udmærket navigere efter flere af disse kriterier på samme tid i sin vurdering af litteratur, herunder prioritere dem forskelligt i forhold til forskellige genrer. Hensigten med spørgsmålet er i lyset heraf at få læseren til at prioritere mellem forskellige kriterier for, hvad der bedst kendetegner en god roman. Hver respondent har fået mulighed for at vælge op til to kriterier. 


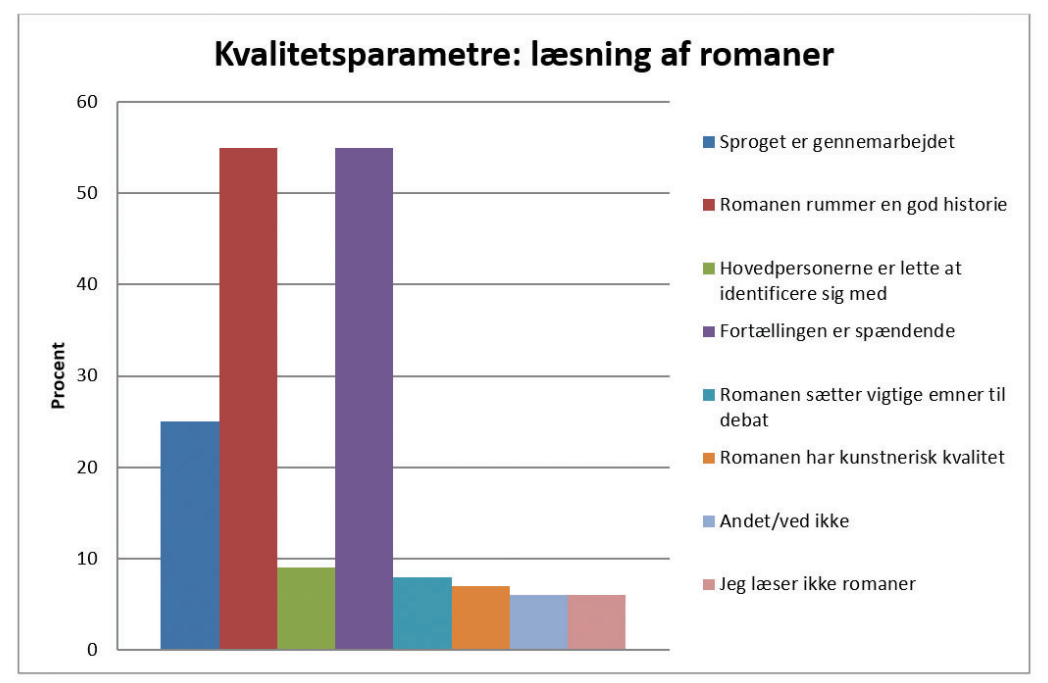

Figur 16. Svar på spørgsmålet: "Hvad synes du bedst karakteriserer en god roman?" Kvalitetsparametre ved læsning af skønlitterære romaner blandt danske læsere. Respondenter kan give op til 2 svar. Egen undersøgelse i samarbejde med TNS Gallup. N=1535. Univers er alle, der læser bøger, i aldersgruppen fra 18 år og opefter.

Som det fremgår af figur 16, er de oplevelsesorienterede kvalitetsparametre "romanen rummer en god historie" (55\%) og "fortællingen er spændende" (55\%) klart de mest foretrukne blandt danske læsere. Spørgsmålet om identifikation med hovedpersoner (9\%) ser ud til at spille en langt mindre rolle for vurderingen af, om en roman er god eller ej. Ser vi på de vurderende kvalitetsparametre, finder de generelt lav tilslutning. Om en roman kan siges at have kunstnerisk kvalitet, er kun en prioritet for 7\% af læserne. For $8 \%$ er det et kvalitetskriterium, om romanen sætter vigtige emner til debat, mens hele $25 \%$ finder det vigtigt, at sproget er gennemarbejdet. Af de vurderende kriterier er den sproglige kvalitet således langt mere fremtrædende end kunstneriske egenskaber og samfundsrelevans. Denne type survey-spørgsmål med kvalitative svarmuligheder rummer altid en risiko for, at svarmulighederne ikke er udtømmende i forhold til, hvad læsere måtte finde relevant at svare på spørgsmålet. I dette tilfælde peger de meget lave svarprocenter for 'andet' (1\%) og 'ved ikke' (5\%) dog på, at respondenterne har fundet svarmulighederne relevante og udtømmende.

I lyset af disse svar vil vi i det følgende gruppere læserne i forhold til de to grupper af kvalitetskriterier, de fremhæver, sådan at vi kan belyse forholdet mellem læsere med præference for henholdsvis en vurderende og en oplevende type af læsning (figur 17). En præference for den vurderende læsning bygger på, at læseren har prioriteret mindst ét af de tre vurderende kvalitetskriterier; tilsvarende skal læseren have angivet mindst ét af de tre oplevelsesorienterede kvalitetskriterier for at blive placeret i gruppen med præference for en oplevende læsning. Da der har været mulighed for at angive op til to svar, kan nogle læsere tilknyttes begge typer af læsning. Hensigten er ikke, at de to læsetyper skal opfattes som gensidigt udelukkende, idet en given læser i virkelighedens verden kan have flere kvalitetskriterier, 
der indgår med forskellig vægt. Distinktionen er således baseret på respondentens positive fremhævning af udvalgte kriterier, ikke definitiv udelukkelse af andre. Det er dog interessant, at det kun er 19\% af læserne, hvis præferencer går på tværs af de to typer af læsning. 37\% af læserne prioriterer den vurderende læsetype, 82\% prioriterer den oplevende læsertype, hvilket gør den oplevende læsning til den klart mest foretrukne.

Vurderende
læsetype
- "Sprogeter
gennemarbejdet"
- "Romanen sætter
vigtige emner til
debat"
- "Romanen har
kunstnerisk
kvalitet"
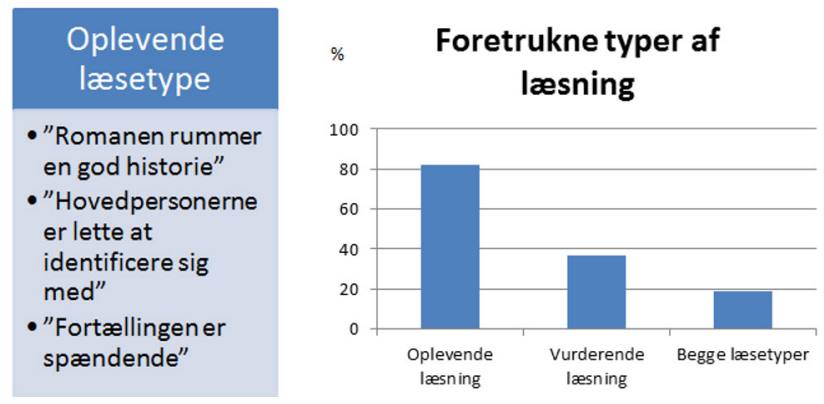

Figur 17. Typologi med to læsetyper konstrueret på baggrund af svar på spørgsmålet: "Hvad synes du bedst kendetegner en god roman?” Egen undersøgelse i samarbejde med TNS Gallup. N= 1535. Univers er alle danske læsere fra 18 år og opefter. Eftersom respondenter havde op til 2 svarmuligheder, kan en læser godt falde ind under begge læsetyper.

Læsetyperne er blevet konstrueret på baggrund af en teoretisk model om indflydelse fra forskellige institutionelle sammenhænge med tilhørende kvalitetskriterier (figur 1) samt Mukařovskýs receptionsteoretiske overvejelser, og vi skal nu se, om der også er empirisk sammenhæng mellem præference for læsetyper og læsernes erfaring med de forskellige institutioner. Hvis vi først ser på skolen eller uddannelsessystemet som institution, kan vi af figur 18 se, at præference for læsetype har en vis sammenhæng med forskellig uddannelsesmæssig ballast. Det er ikke mindst en længerevarende uddannelse på fem år eller mere, der ser ud til at have en indflydelse på, hvorvidt vurderende kriterier har betydning. Det er endvidere værd at notere sig, at der trods forskelle også er et betydeligt overlap mellem de to læsetyper, hvad angår uddannelse.

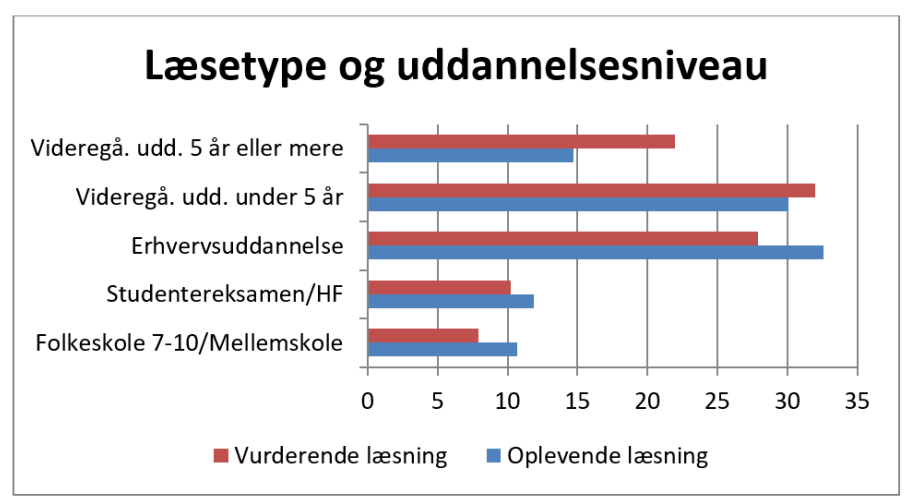

Figur 18. Uddannelsesniveau i forhold til vurderende og oplevende læsetyper. I procent af målgruppen. Egen undersøgelse i samarbejde med TNS Gallup. N=1535. 
For at belyse læsetypernes sammenhæng med læsernes erfaring med kunstinstitutionen i almindelighed og den litterære institution i særdeleshed vil vi anvende to typer af indeks for dette. Hyppigheden af besøg på kunstmuseer vil blive anvendt som indeks for læserens generelle fortrolighed med kunstverdenen som institution; dernæst vil brug og vurdering af boganmeldelser blive anvendt som indeks for erfaring med den litterære institutions vurderingskriterier (Furuseth 2013); litteraturkritik i form af boganmeldelser kan siges at være den litterære institutions mest synlige virksomhed og dermed mere anvendelig i en survey end spørgsmål vedrørende fx litterære priser, der forudsætter en mere specialiseret viden. Som det fremgår af figur 19, er der en tydelig sammenhæng mellem foretrukken type af læsning og generel fortrolighed med kunst. Jo hyppigere man går på kunstmuseum, desto mere vil man foretrække en vurderende læsning, og jo mindre man går på kunstmuseum, desto mere vil man gå efter en oplevende læsning.

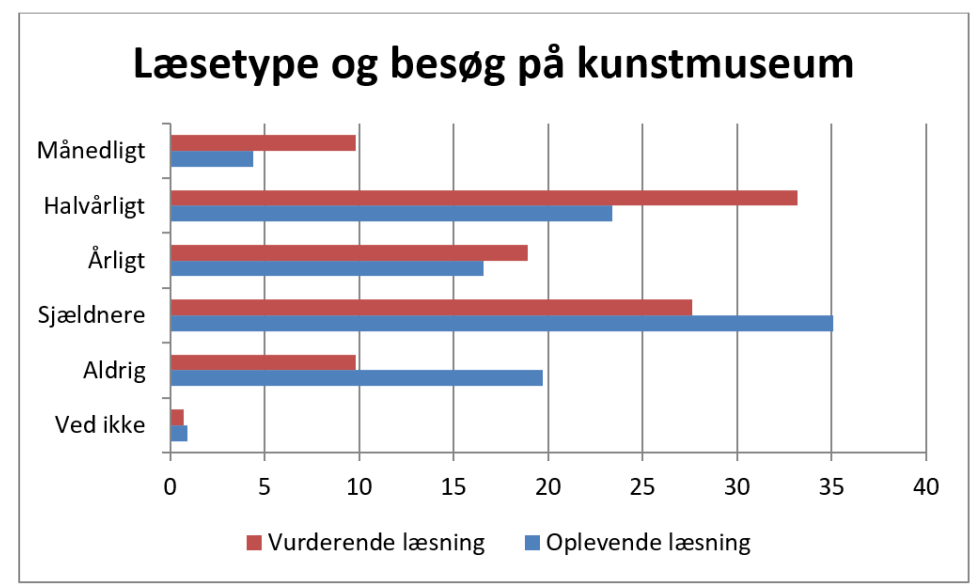

Figur 19. Hyppighed af besøg på kunstmuseum set i forhold til foretrukken læsetype. I procent af målgruppen. Egen undersøgelse i samarbejde med TNS Gallup. N=1535. Univers er alle, der læser bøger, i aldersgruppen fra 18 år og opefter.

\section{Anmeldelsens varierende autoritet blandt læserne}

Som nævnt er boganmeldelser blandt de vigtigere inspirationskilder, når læseren søger efter ny litteratur. Spørgsmålet er dernæst, om de vurderinger, som anmeldelser rummer, også er vigtige for det endelige valg af bog, herunder om denne tilskrivning af autoritet hænger sammen med den foretrukne læsetype. Generelt peger læsernes svar på, at anmelderes vurderinger er mindre vigtige. $49 \%$ af alle læsere finder, at anmeldelser er mindre vigtige eller slet ikke vigtige for deres valg af bøger, mens 35\% siger, anmeldelser i nogen grad er vigtige. En mindre gruppe af læsere på $12 \%$ finder, at anmeldelser i høj eller meget høj grad er vigtige for deres valg af bog. Som det fremgår af figur 20, gør der sig her nogle klare uddannelsesmæssige forskelle gældende. Især blandt personer med en videregående uddannelse på fem år eller mere er man tilbøjelig til at lade bogvalget være påvirket af anmeldelser. Her siger 45\%, at anmeldelser i nogen grad er vigtige, mens 17\% siger, at anmeldelser i høj eller meget høj grad er 


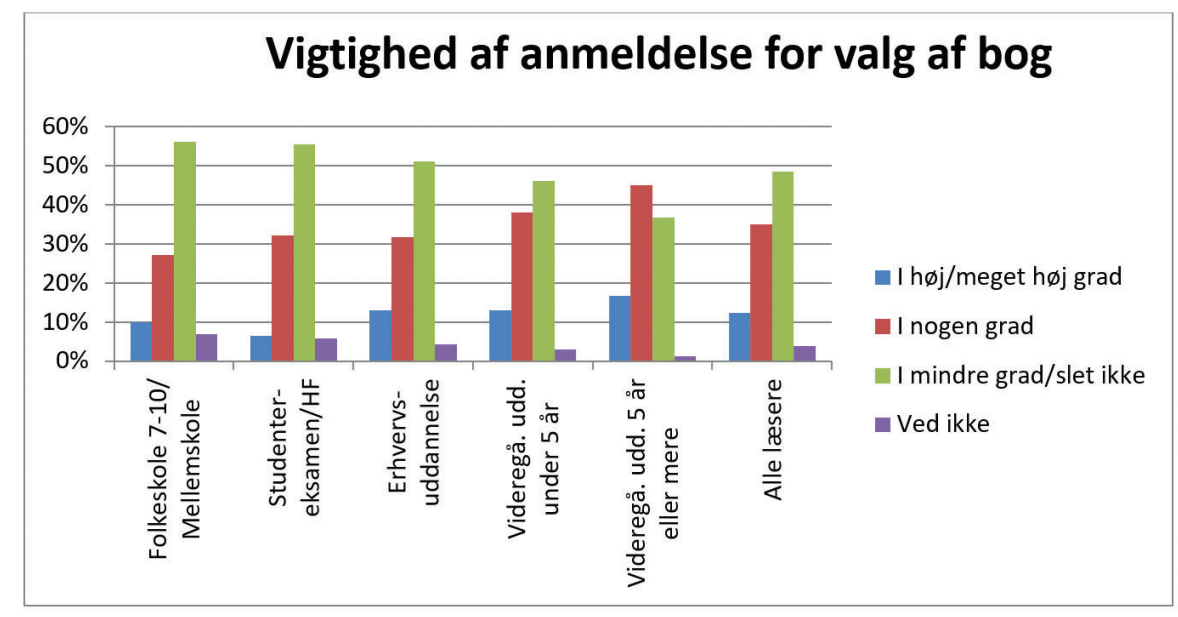

Figur 20. Uddannelsesniveau set i forhold til besvarelse af spørgsmålet: "I hvilken grad synes du, at en boganmeldelse er vigtig for dit valg af bog?". Egen undersøgelse i samarbejde med TNS Gallup. N=1535. Univers er alle, der læser bøger, i aldersgruppen fra 18 år og opefter.

vigtige for bogvalget. En længerevarende uddannelse er således med til at højne anmeldelsers autoritet i læserens øjne, mens hovedparten af befolkningen ikke vil tilskrive anmeldelsers smagsdomme større værdi.

I forlængelse af den teoretiske model (figur 1) kan vi også se en forskel i anmeldelsers værdi for læseren i forhold til, om læseren fortrinsvis anlægger vurderende eller oplevelsesorienterede kvalitetskriterier på litteratur. Hvis læseren foretrækker en vurderende læsetype, vil han eller hun i større grad tillægge anmeldelser værdi for valget af litteratur, mens den oplevelsesorienterede læser finder dem mindre vigtige (figur 21). Denne sammenhæng afspejler sig også i, hvor ofte man faktisk læser anmeldelser, idet den vurderende læser oftere læser anmeldelser end den oplevelsesorienterede læser. Dette forhold bliver endnu mere udtalt, hvis vi alene ser på den mindre gruppe af læsere, der lægger vægt på, at en bog har kunstnerisk kvalitet. Som det fremgår af figur 22, angiver $42 \%$ af disse læsere, at de læser anmeldelser mindst en gang om ugen, mens kun 8\% af læsere, for hvem "fortællingen er spændende" er et vigtigt parameter, læser anmeldelser mindst en gang om ugen.

Samlet set kan vi altså konkludere, at både skolen og den litterære institution udøver en vis indflydelse på læsernes præferencer for litteratur og læsetyper. Jo større fortrolighed med disse institutioner (i form af længde af uddannelse og læsning af anmeldelser), desto større forkærlighed for en vurderende læsetype, der trækker på kvalitetskriterier fra de to institutioner. Men det er samtidig værd at understrege, at langt hovedparten af befolkningens læsning hælder til en mere oplevende læsetype, der i højere grad henter sine kvalitetskriterier i den bredere populær- og mediekultur. Endelig er det vigtigt at huske, at spørgsmålet om, hvorvidt man overhovedet læser bøger eller ej, også hænger sammen med uddannelsesmæssige og økonomiske faktorer. 


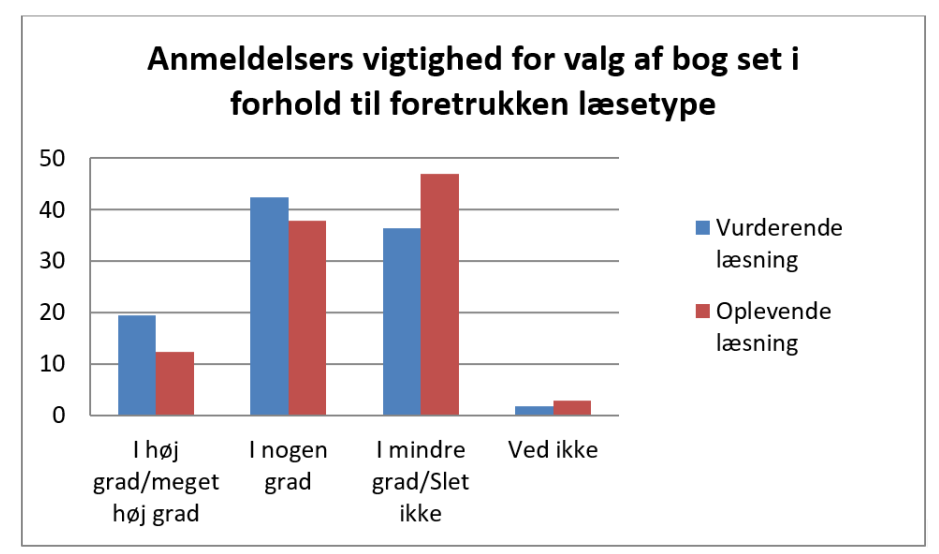

Figur 21. Foretrukken læsetype i forhold til vurdering af anmeldelsers vigtighed. I procent af målgruppen. Egen undersøgelse i samarbejde med TNS Gallup. N=1535. Univers er alle, der læser bøger, i aldersgruppen fra 18 år og opefter.

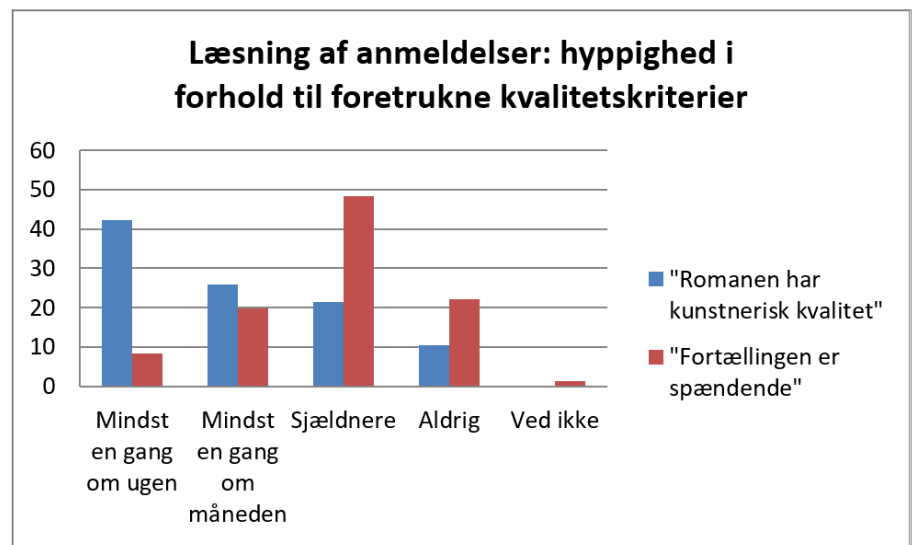

Figur 22. Hyppigheden af læsning af anmeldelser set i forhold til udvalgte kvalitetskriterier for bøger. I procent af målgruppen. Egen undersøgelse i samarbejde med TNS Gallup. $\mathrm{N}=1535$. Univers er alle, der læser bøger, i aldersgruppen fra 18 år og opefter.

\section{Konklusion}

Formålet med denne artikel har været at give en analyse af danskernes brug af og præferencer for litteratur med særligt henblik på skønlitteratur. I punktform er de vigtigste resultater af den deskriptive del af analysen følgende:

- Kriminallitteratur er den genre, som flest læsere foretrækker. Dernæst følger skønlitteratur uden bestemt genre og historiske romaner. Genrepræferencer hænger i et vist omfang sammen med køn, alder og uddannelse.

- Læsning af e-bøger er gradvist ved at vinde frem, især blandt yngre, og læsningen foregår primært på mobile skærme som tablets og mobiltelefoner; blandt de helt unge også på computerskærme. Med den nuværende udbredelse af e-læsning, er e-bogslæsere kendetegnet ved at være særligt flittige læsere, der hyppigere end rene papirbogslæsere taler med andre om bøger og giver bøger i gave.

- Den vigtigste inspirationskilde til læsernes valg af bøger er samtaler med venner og bekendte; dernæst følger biblioteket, anmeldelser i dagbladet og boghandelen, 
såvel online som offline. Selvom anmeldelser er en udbredt inspirationskilde, er der betydelige forskelle i læsernes opfattelse af anmeldelsernes væsentlighed for valg af bøger. Især læsere med en lang videregående uddannelse finder anmeldelser vigtige.

- Danskernes læsning af skønlitteratur er fortrinsvis motiveret af et ønske om underholdning og afslapning for sig selv, men bøger tjener samtidig sociale formål som samtaleemne og gaveobjekt.

- Danske læsere lægger primært vægt på to oplevelsesorienterede kriterier ved vurderingen af, om en roman er god: hvorvidt romanen rummer en god historie, og fortællingen er spændende. Vurderende kriterier vedrørende romanens kunstneriske kvalitet og emnets samfundsmæssige relevans spiller en klart mindre rolle for kvalitetsvurderingen.

I tillæg til den deskriptive del af analysen er der også blevet påvist en række systematiske sammenhænge mellem smagspræferencer, læseadfærd og social stratifikation. Økonomi og uddannelse spiller en rolle for, om danskerne overhovedet er læsere af fag- og skønlitteratur, og uddannelse spiller en rolle for, hvilke præferencer læseren har for litteratur, og hvilke kvalitetskriterier der anlægges. En betydelig majoritet af danske læsere har præference for en oplevelsesorienteret læsning, mens en mere distanceret, vurderende læsning prioriteres af en mindre del af læserskaren. Præferencen mellem de to læsetyper er delvist sammenhængende med læsernes forskellige grad af fortrolighed med tre institutionelle kontekster: uddannelsessystemet, den litterære institution og mediernes populærkultur. Det er især gruppen af læsere med den længste videregående uddannelse, som adskiller sig fra den øvrige del af befolkningen, og her finder man en betydeligt større interesse for at se på litteratur som kunst, ligesom man tilskriver litterære anmeldelser større autoritet for valg af litteratur.

Forskellige kulturteorier har forsøgt at problematisere sammenhænge mellem smagspræferencer og kulturforbrug på den ene side og sociale (klasse)skel på den anden side. Hvor Bourdieus (1989) kunstsociologi ikke mindst havde til formål at demonstrere, hvordan smag indgår i reproduktionen af kulturelle og sociale hierarkier, er disse antagelser blevet både udviklet og udfordret på forskellig måder. Peterson (1992) har således argumenteret for, at den traditionelle skelnen mellem en differentieret elitekultur på den ene side og en homogen massekultur på den anden side ikke er holdbar, og i stedet argumenterer han for en skelnen mellem 'omnivores', der konsumerer mange forskellige typer af kultur af såvel finkulturel som trivial karakter, og 'univores', hvis smagsløg er mere endimensionale. Mere generelt har postmoderne teori plæderet for en relativisme, hvor traditionelle smagshierarkier er om ikke opløst, så under tydelig om- og nedbrydning. Analysen af danskernes smagspræferencer og læseadfærd peger på, at danskernes brug af og smag for litteratur fortsat er socialt stratificeret, hvor ikke mindst gruppen af danskere med en længerevarende uddannelse er bærer af en forståelse af litteratur som kunst, mens hovedparten af befolkningen lægger andre kriterier til grund for deres valg af litteratur. Denne gruppe er samtidig i højere grad fortrolig med både kunstinstitutionen i almindelighed og den litterære anmeldervirksomhed. Der er således ikke belæg for en simpel postmoderne relativisme eller forestilling om opløsning af sociale og 
kulturelle skel. Til gengæld kan eksempelvis distinktionen mellem 'omnivores' og 'univores' give en fornyet belysning af den sociale stratifikations betydning for kulturpræferencer og -adfærd, idet graden og måden, hvorpå fx den altædende 'spiser' kulturelle produkter, er informeret af hans eller hendes sociale position. I denne artikel giver eksempelvis genrepræferencernes sammenhæng med køn, alder og uddannelse et fingerpeg om dette, men en nærmere udforskning af dette ligger uden for denne artikels rammer.

Man kan videre diskutere, i hvilket omfang den veluddannede sociale gruppes smag egentlig har større indflydelse på, endsige udøver hegemoni over den øvrige del af befolkningens litteraturforbrug og smag. En betydelig del af befolkningen tilskriver ikke litterære anmeldelser stor værdi for valg af litteratur, mens de for nogle har en vis autoritet og kan bidrage med inspiration til valg af nye bøger. Hvis den kulturelle elites norm i realiteten ikke er en dominerende norm, bør vi - med en rumlig metafor - supplere vores traditionelle lodrette stratifikation med en vandret stratifikation. Den traditionelle beskrivelse af stratifikationen som et vertikalt kulturelt hierarki, hvor de veluddannedes litteratursmag og vurderende form for læsning befinder sig øverst og udøver en form for normsættende tvang på den underliggende befolknings litteraturbrug, er kun delvist korrekt. Stratifikationen rummer også en horisontal spredning, hvor den populære litteratursmag og oplevelsesorienterede læsning dominerer centrum, mens den kunstorienterede smag og vurderende læsning befinder sig i yderkanten som et mere marginalt fænomen.

Afslutningsvist skal det nævnes, at hovedparten af befolkningens præferencer for skønlitteratur vidner om de smagsmønstre, herunder genrepræferencer, man kender fra den øvrige mediekultur, ikke mindst fiktionsmedier og -genrer som tvdrama og film. Set i dette lys, er en bedre indgangsvinkel til at forklare danskernes smag for litteratur at belyse den i sammenhæng med de generelle mønstre og forskelle i danskernes medie- og kulturbrug. Kun at belyse smag i forhold til litteratur giver en begrænset horisont til forståelse af smagspræferencer. Dette hænger naturligvis også sammen med en historisk udvikling, hvor litteraturens område er blevet genstand for en medialisering, hvor dele af litteraturens kredsløb, herunder smagspræferencer, præges af mere generelle institutionelle logikker fra populærkulturens felt.

\section{Litteratur}

Agger, Gunhild (2010): “Approaches to Scandinavian Crime Fiction”, i Crime Fiction and Crime Journalism in Scandinavia, Working Paper nr. 15, Aalborg: Aalborg University.

Balling, Gitte (2009): Litterær æstetisk oplevelse: Læsning, læseoplevelser og læseundersøgelser: en diskussion af teoretiske og metodiske tilgange, ph.d.-afhandling, København: Danmarks Biblioteksskole. Balling, Gitte (2013): “Om læseoplevelsen. Et indblik i læseoplevelsens egenskaber og betydning”, i Viden om læsning 7.14, s. 26-33.

Berntsen, Dorthe og Larsen, Steen Folke (1993): Læsningens former, Aalborg: Forlaget Biblioteksarbejde.

Bourdieu, Pierre (1989): Distinction. A Social Critique of the Judgement of Taste, London: Routledge. 
Escarpit, Robert (1972): Bogen og læseren. Udkast til en litteratursociologi, København: Hans Reitzels Forlag. Furuseth, Sissel (2013): "Fra recepsjon til produksjon: litteraturkritik som kulturell praksis", i Jofrid Karner Smidt, Tonje Vold og Knut Oterholm (red.): Litteratursosiologiske perspektiv, Oslo: Universitetsforlaget, s. 141-167.

Handesten, Lars (2014): Bestsellere. En litteratur- og kulturhistorie om de mest solgte bøger i Danmark siden 1980, Odense: Forlaget Spring.

Harrits, Gitte Sommer (2014): Klasse. En introduktion. København: Hans Reitzels Forlag.

Hertel, Hans (1999): "Bogen på mediernes supermarked. Kulturdemokratisering, polarisering og mediesymbiose 1945-98”, i Litteraturens vaneforbrydere, København: Gyldendal, s. 16-38.

Hjarvard, Stig og Helles, Rasmus (2013): "Digital Books on the Point of Take-off? The Ebook in Denmark Anno 2013”, i Academic Quarter 7, s. 34-50.

Hjarvard, Stig og Rasmus Helles (2015): "Going Digital. Changing the Game of Danish publishing”, i Northern Lights 13.1, s. 49-64.

Hjarvard, Stig (2016): “Medialisering. Institutioner, logikker og dynamikker”, i Stig Hjarvard (red.): Medialisering. Mediernes rolle i social og kulturel forandring, København: Hans Reitzels Forlag, s. 39-70.

Kristensen, Nete Nørgaard og From, Unni (2015): "From Ivory Tower to Cross-Media Personas. The Heterogeneous Cultural Critic in the Media", i Journalism Practice 9.6, s. 853-871.

Kulturministeriet (2012): Danskernes kulturvaner 2012, rapport udarbejdet af Epinion A/S og Pluss Leadership A/S, København: Kulturministeriet.

Kulturstyrelsen (2015): Bogen og litteraturens vilkår 2015, rapport fra Bog- og litteraturpanelet, København: Kulturstyrelsen.

Kulturstyrelsen (2016a): Mediernes udvikling i Danmark 2016, København: Kulturstyrelsen.

Kulturstyrelsen (2016b): Bogen og litteraturens vilkår 2016, rapport fra Bog- og litteraturpanelet. København: Kulturstyrelsen.

Mukařovský, Jan (1943 [1977]): "Intentionality and Unintentionality in Art", i John Burbank and Peter Steiner (red.): Structure, Sign and Function. Selected Essays by Jan Mukařovský, New Haven: Yale University Press, 89-128.

Nightingale, Virginia (red.) (2011): The Handbook of Media Audiences, Malden: Wiley-Blackwell.

Palmer, Jerry (1990): "Genrer og medier. Et kort overblik", i MedieKultur 6.14, s. 5-17.

Peterson, Richard A. (1992): "Understanding Audience Segmentation. From Elite and Mass to Omnivore and Univore", i Poetics 21, 243-258.

Phillips, Angus (2014): Turning the Page. The Evolution of the Book, London: Routledge.

Povlsen, Karen Klitgaard (2016): “Bøger! Bøger! Bøger!”, i Klaus Bruhn Jensen (red.): Dansk Mediehistorie bd. IV, Frederiksberg: Samfundslitteratur, s. 217-243.

Schiffrin, André (2010): Words \& Money, London: Verso.

Smidt, Jofrid Karner (2011): “Litteratursosiologi og estetikk - Jan Mukařovský revisited”, i Sakprosa 3.2.

Smidt, Jofrid Karner, Tonje Vold og Knut Oterholm (red.) (2013): Litteratursosiologiske perspektiv, Oslo: Universitetsforlaget.

Thornton, Patricia H., William Ocasio og Michael Lounsbury (2012): The Institutional Logics Perspective. A New Approach to Culture, Structure, and Process, Oxford: Oxford University Press.

Thompson, John B. (2010): Merchants of Culture. The Publishing Business in the Twenty-First Century, Cambridge: Polity.

Williams, Raymond (1958 [1989]): "Culture is Ordinary", i Raymond Williams (red.): Resources of Hope, Culture, Democracy, Socialism, London: Verso, s. 3-18. 